| Araştırma Makalesi / Research Article |

\title{
Hadi Oynayalım: Okul Öncesi Çocukların Otorite, Kural ve Kural İhlalini Oyun Bağlamında Değerlendirmeleri
}

\section{Let's Play: Preschool Children's Judgments of Authority, Rule, and Rule Violations in the Context of Play}

\section{Melike Acar ${ }^{1}$, Ayşegül Özen², Özge Kılıç3}

Anahtar Kelimeler
kural ve otorite
okul öncesi
ahlaki sorgulama
sosyal gelişim

\section{Keywords}

rules and authority

preschool

moral reasoning

social development

Başvuru Tarihi/Received

11.11.2019

Kabul Tarihi /Accepted

25.02.2020
Öz

Bu çalışmanın amacı Sosyal Alan Kuramını (Turiel, 1983) kullanarak okul öncesi dönemdeki çocukların iki farklı oyun bağlamında otorite, kural ve kural ihlaline yönelik değerlendirme ve gerekçelerini incelemektir. Bu amaçla, 3 farkı sosyoekonomik düzeydeki okul öncesi kurumuna devam etmekte olan 5 yaş grubundan toplam 37 (21 kız, 16 oğlan) çocukla yarı yapılandırıımış klinik görüşmeler yapılmıştır. Çalışmanın sonuçları Sosyal Alan Kuramıyla yapılan diğer çalışmaların bulgularıyla tutarlı olup çocukların ahlaki alanla sosyal-geleneksel alanı farklı değerlendirdiklerini göstermiştir. Ahlaki alan içerisinde tanımladıkları basketbol oyununda rakibi geçmek için vurmak kuralını otoritenin kaldırmasını olumsuz değerlendirmişler ve kuralın yokluğunda bile vurmanın yanlışlı̆ını "başkasına zarar vermeme" ilkesine dayandırarak gerekçelendirmişlerdir. Bulgular Sosyal Alan Kuramı bağlamında erken çocuklukta sosyal gelişim ve oyun ilişkisine değinilerek tartışılmıştır.

\section{Abstract}

The primary purpose of this study was to examine preschool children's judgment and justifications about authority, rules, and rule violations in the play context by using Social Domain Theory (Turiel, 1983). A total of 37, 5-years-old preschool children (21 girls, 16 boys) from three different preschools were individually interviewed by using semi-structured clinical interviews. Results were consistent with other research findings using Social Domain Theory and revealed that preschool children differentiated the moral domain from the social-conventional domain. Children defined basketball within the moral domain by disapproving the authority who changed the rule of no harm. They evaluated physical harm to the opponent as not acceptable by using the "no harm" principle. The discussion section focused on the relationship between play and social development during early childhood.

${ }^{1}$ MEF Üniversitesi, Eğitim Fakültesi, Psikolojik Danışmanlık ve Rehberlik Bölümü, İstanbul, TÜRKiYE https://orcid.org/0000-0003-3233-1042

${ }^{2} 18$ Mart Üniversitesi, Eğitim Fakültesi, Çanakkale, TÜRKiYE

${ }^{3}$ Okul Öncesi Öğretmeni, İstanbul, TÜRKIYE 
Extended Abstract

\section{Introduction}

Studies using Social Domain Theory (Turiel, 1983) with western and non-western participants showed that children as young as 3 were able to differentiate moral issues than social-conventional issues (Smetana, 1981; Smetana \& Braeges, 1990; Yau \& Smetana, 2003). Children judged hitting and pushing a friend as morally wrong by the majority of the children by referring to the well-being of the friend. They also evaluated harming a friend as not acceptable even in the absence of the authority and rules. They generalized the wrongness of the act to the other cultural contexts. However, social conventional issues were defined as social regulations (e.g., wearing the school uniform). They were evaluated depending on the authority dictates and the existence of the rules. They were also viewed as culturally relative. The primary purpose of the present research was to investigate whether Turkish preschoolers from three different SES judged moral rules differently from social conventional rules in the context of the play.

\section{Method}

Semi-structured interviews were conducted in three different preschools with 37 children ( 21 girls, Mage $=64.58$ months old, $s d=3.91$ and 16 boys, Mage $=65.58, s d=2.97$ ). Children were presented with two hypothetical stories. The first story was about a basketball game. The second story was about playing house.

\section{Result and Discussion}

Children were more likely to see that basketball having strict and unchangeable rules (73\%) than playing house (51\%). They saw hitting and pushing the opponent during play as morally unacceptable even if the authority figure removes the rules. They have also assigned less jurisdiction to authority for changing the rules of the basketball game. Most children thought that hitting was not acceptable in basketball because the other child could get hurt. On the other hand, they viewed the rules of playing house as a social conventional and personal issue. They stated not obeying the rule in playing house story was more acceptable than not obeying the rule in the basketball game. Furthermore, children attributed more alterability to the rules of playing house. They were also more likely to confirm the authority when the teacher wanted to change the rules. In the absence of rules, they interpreted not obeying as a more personal choice or social conventional issue.

Results showed that similar to their peers in so-called individualistic and collectivistic cultures Turkish preschoolers could also differentiate the moral domain from the social-conventional domain. Even in the play context children judged physical harm to the other as morally unacceptable, independent of the rule and authority dictates. 
GíRiş

Piaget (1932/1965) çocuklarda kural, otorite ve ahlak kavramlarının gelişimine yönelik argümanlarını oyun oynayan çocuklara yönelik gözlemlerine ve onlarla yaptığı görüşmelere dayandırır. Piaget'e göre erken çocuklukta çocuklar oyunun mucidinin yetişkinler ya da çocuğu aşan aşkın bir güç olduğu inancındadır. Oyunların kurallarını değiştirilemez olarak değerlendirirler ve kuralların değişmezliği konusunda oldukça sabit fikirlidirler. Piaget, kurallar konusundaki bu sabit fikirlilik ve otoriteye kayıtsız şartsız itaat dönemini (5-9 yaşları arası) heteronom/dışabağımlı ahlak olarak tanımlanmıştır. Bilişsel, duygusal ve sosyal-biliş alanlarında özerkleşemeyen çocuk zihni, heteronom dönemde otorite figürlerinin özellikle de ebeveynlerinin koyduğu kurallara bağlıdır, otoriteyi ve kurallarını sorgulamaz. Piaget aşamalarla ve bütüncül olarak açıkladığı zihin gelişimi kuramında bilişsel gelişimi sosyal ve ahlaki gelişimin önkoşulu olarak tanımlar. Bilişsel olarak işlem-öncesi dönemden çıkıp somut işlem döneminin sonlarına doğru çocuklarda otonom/özerk bir ahlaki sorgulama görülebilir. Piaget'ye göre çocuklar ancak otonom aşamada kuralların bazı durumlarda esneyebileceğini, otorite figürlerinin ise her durumda kadir-i mutlak olmadığını kavramaya başlar. Piaget'ye göre otonom aşamada ahlak eşitler arasındaki ilişkinin sonucu olarak gelişir. Kısacası, heteronom dönemde otoriteyi mutlu etmek ve cezadan sakınmak için kuralları sorgulamadan uygulamak otonom ahlakın ön koşulludur. Aşamalı gelişimin kuramsal varsayımına göre her çocuk önce heteronom/dışa bağımlı aşamadan geçer. Hem bilişsel alanda hem de sosyal-ahlaki alanda bir aşamanın gerekli özelliklerini geliştirmeden bir sonraki aşamaya geçemez. Aşamadan aşamaya gelişme dış faktörlerle hızlandırılamaz. Piaget'in kuramında çocuk aktif olarak dünyayı sorup sorgulayarak, deneyimleyerek ve yaşıtlarıyla oyun oynayarak gelişir.

Halbuki, okulöncesi dönemde çocuğu olan, çocuklarla çalışan, çocuklarla vakit geçiren, oyun oynayan pek çok yetişkin çocukların kurallara ve otorite figürüne Piaget'in ileri sürdüğü gibi kayıtsız şartsız itaat etmediğine tanıklık etmiştir. Özellikle son 30 yılda çocuklarla yapılan hem batı hem de batı dışı kültürlerde yapılan akademik çalışmalar bize okul öncesi dönemdeki çocukların kurallara ve otoriteye yönelik değerlendirmelerinin Piaget'in sandığından çok daha sofistike ve bağlama göre değişken olduğunu göstermektedir (Smetana, 1981; Smetana \& Braeges, 1990; Turiel, 1983; Song, Smetana \& Kim, 1987). Bu çalışmalarda, Piaget'nin de kullandığı klinik görüşme ve gözlem teknikleri kullanılarak çocukların ahlaki kurallar, diğer sosyal kurallar ve bunların otoriteyle olan ilişkisini nasıl değerlendirdikleri araştırılmıştır. Bu çalışmaların sonuçları bize çocukların yaklaşık 3 yaşından itibaren ahlaki normları diğer sosyal ve kültürel kurallardan sistematik olarak ayrıştırdığını göstermektedir. Örneğin "arkadaşa vurmamak" kurallını çocuklar ahlaki olarak yanlış bulmuşlardır. Bir kimseye bilerek isteyerek zarar vermeyi, canını yakmayı yanlış olarak değerlendirmişler, bunu da "ötekinin canı yanar", "üzülür", "haksızlık olur" gibi cümlelerle gerekçelendirmişlerdir. Bu durumda "zarar vermeme" kuralının değişmeyeceğini, ötekini korumak adına hiçbir koşulda değiştirilmemesi gerektiğini savunmuşlardır (Turiel, 1983). Yine bu çalışmaların bulguları bize çocukların ahlaki kuralları evrensel ve otoriteden bağımsız olarak değerlendiklerini göstermiştir. Mesela, "diyelim ki başka bir okulda, ya da başka bir ülkede vurmak ile ilgili hiç kural yok, o zaman vurmak uygun olur mu?” sorusunu olumsuz değerlendirmişler, otorite figürü olan öğretmenler ve ebeveynler bu kuralı kaldırsa bile vurmanın yanlışığını savunmuşlardır. Yine araştırmaların sonuçları bize çocukların sosyal ortamı düzenleyen kuralları (örn., okula giderken üniforma giymek, sınıfta parmak kaldırmadan konuşmamak) ahlaki kurallardan daha farklı değerlendirdiklerini göstermiştir. Çocuklar kamusal alanı düzenleyen sosyal-geleneksel kuralları otoriteye bağlı olarak değerlendirmişler, bu kuralların kültürden kültüre, hatta mahalleden mahalleye bile değişiklik göstereceği vurgusunu yapmışlardır. Sosyal Alan Kuramı çerçevesinden yapılan araştırmalar çocukların erken çocukluk yıllarından itibaren otoritenin meşrutiyetini sorguladıklarını göstermiştir (Laupa \& Turiel, 1986). Örneğin, çocuklar öğretmenin otoritesini sadece okul bağlamında meşru görürken, ebeveynlerinin otoritesinin sadece ev ortamında geçerli olduğunu söylemişlerdir (Laupa \& Turiel, 1993). Sosyal Alan Kuramında, ahlaki ve toplumsal-geleneksel alandan farklılaşan diğer sosyal alan da kişisel alandır. Kişisel alanı kısaca özerklik ve kişisel özgürlük alanı diye tanımlayabiliriz (Nucci, 1981). Kişisel alan yapısı gereği bireye özeldir ve bu alanda verilen kararlar doğru ve yanlış diye değerlendirilemezler. Örneğin bir çocuk kırmızı rengi çok severken diğeri yeşil rengi tercih etmektedir. Bu seçimler çocuğun kişisel seçimleridir ve çocuğun kişisel alanına saygı duymak sosyal sorgulamanın ve özerkliğin gelişebilmesi için önemlidir.

Öte yandan, ahlakın kültürün bir parçası olduğunu, dolayışla da göreceli olarak otorite figürleri aracılığıyla (aile, okul, devlet) ödül ve ceza mekanizmalarıyla nesilden nesile sorgulanmadan aktarılan değerler bütünü olduğu varsayımı psikolojide davranışçılı (Skinner, 1971) ve daha sonra sosyal öğrenme kuramları (Bandura, 2002) tarafından ortaya atılmıştır. Bu yaklaşımlar hem bilişsel gelişimi hem de sosyal gelişimi davranış kazanımı ve değişimi olarak tanımlar. Yukarıda kısaca özetlenen ahlaki gelişim teorilerinin aksine bu kazanım sürecinde çocuğun aktif özne olduğu ve dış gerçekliği kendi zihninde ölçüp tarttığı varsayımına karşı çıkılır. Bu yaklaşıma göre evrensel bir ahlaki sorgulamadan bahsedilemez, çünkü ahlak görecelidir. Her toplumun kendi ahlak yasası vardır, toplumlar kendi devamlarını sağlamak için bu kurallar bütününü yukarıdan-aşağıya öğretmek zorundadırlar (Durkheim, 1925/1961). Sosyal öğrenme kuramında ahlak, toplumda uyulması gereken kurallar bütünüdür. Dolayısıyla hem Piaget'nin aşamalı gelişime ve hem de sosyal alan kuramcılarının ahlaki alan- sosyal geleneksel alan ayrışımını gösteren ampirik verilerini, ahlakı kültür ve dini değerlere indirgeyerek yorumlamaktadırlar. Eleştirilerin ardındaki temel argümanlardan biri de batı odaklı olan yapılandırmacı gelişim kuramlarının batı dışındaki kültürlerde büyüyen çocukların gelişimini açıklamayacağına yapılan vurgudur. Bu eleştiriler dikkate alınarak batı dışı kültürlerde çocukların ahlaki sorgulamasının gelişimini araştıran çalışmalar yapılmış ve Kore (Song, Smetana, \& Kim, 1987), Çin (Yau \& Smetana, 2003), Japonya (Killen \& Sueyoshi, 1995) gibi toplulukçu olarak tanımlanan uzak-doğu kültürlerinde bile çocukların evrensel ahlaki normları toplumsal-geleneksel kurallardan ayırdığı bulunmuştur.

Erken çocuklukta ahlak kavramı konulu Türkçe alan yazını ise iki grupta inceleyebiliriz. Birinci grup ahlak kavramını milli ve manevi değerler çerçevesinden tanımlayarak değerler eğitimi bağlamında okul öncesi çocuklara nasıl aktarılması gerektiğine odaklanmıştır (Oruç, 2010). İkinci grup çalışmalar ise çocuklarda ahlaki sorgulamanın gelişiminden ziyade çocukların ahlaki ve sosyal-geleneksel kural bilgisini yordayan bireysel ve sosyo-kültürel faktörleri araştırmıştır (Seçer, Sarı ve Olcay, 2006). Bu yazın,

| Kastamonu Eğitim Dergisi, 2020, Vol. 28, No. 3| 
Sosyal Alan kuramcılarından Smetana'nın (1981) yılında çocuklarda ahlaki alan ve sosyal-geleneksel alan farklılaşmasını ortaya koymak için geliştirdiği görüşme protokolünün Türkçe uyarlaması kullanılarak yapılan araştırmalara dayanmaktadır. Smetana'nın (1981) klinik görüşme protokolünü Seçer ve Sarı (2006) "Türk kültürüne adapte” ettiklerini iddia ederek Ahlaki ve Sosyal Kural Algısı Ölçeği” isimli ölçek haline getirmişlerdir ve çocukların ahlak ve sosyal kural puanlarını hesaplamışlardır. Ancak Smetana (1981) ve diğer sosyal alan teorisyenlerinin (Turiel, 1983) araştırma metodu çocukların değişik sosyal durumları nasıl değerlendiklerine ve değerlendirmelerini nasıl gerekçelendirdiklerine odaklanmaktadır. Türkçeye çevrilen ölçek çocuklardan ahlaki (Örn., bir çocuk bir başka çocuğa vurmaktadır; bir çocuk oyuncak ayısını arkadaşıyla paylaşmamaktadır.) ve sosyal-geleneksel (Örn., bir çocuk arkadaşlarıyla oyuna katılmamaktadır; bir çocuk okuldaki hikâye saatinde, oturması gereken yere oturmamaktadır) kuralları ihlal eden davranışları değerlendirmeleri istenmektedir. Bu değerlendirmelerden ortalama bir ahlak kural ve sosyalgeleneksel kuram puanı hesaplanmaktadır. Meriç ve Özyürek (2018) okul öncesi çağındaki çocukların ahlak ve sosyal-geleneksel kural bilgisi arasında pozitif yönde bir ilişki bulmuşlardır. Yine bu ölçekle yapılan çalışmalardan bir başka çalışma (Seçer, Çeliköz ve Yaşa, 2007) bilişsel olarak impulsif olan çocukların ahlaki ve sosyal kuralları daha az ciddiye aldığını bulmuşlardır. Özyürek ve Şahin (2015) ise olumlu anne tutumlarının olumlu çocukların ahlaki kural anlayışları arasında pozitif bir ilişki olduğunu belirtmektedir.

Seçer ve Sarı'nın (2006) ölçeği kullanılarak yapılmış çalışmalar, çocuk katılımcı çalışmalar olması ve çocukların değerlendirmelerini yansıtması bakımından Türkçe alan yazısına oldukça değerli katkılar sunmaktadır. Ancak yapılan araştırmaların bulgularının Sosyal Alan Teorisi çerçevesiyle farklı ülke ve kültürlerde yapılan diğer araştırma bulgularıyla birlikte değerlendirilmediği görülmektedir. Ayrıca, yukarıda taranan araştırmalarda hem sosyal alan teorisinin hem de diğer yapılandırmacı ahlak gelişim teorilerinin (Kohlberg 1963, Piaget, 1932/1968) epistemolojik yaklaşımlarıyla çelişen ahlak tanımları yapıldığı görülmüştür. Yapılandırmacı yaklaşımda ahlak "ötekine nasıl davrandığımızdır" (Turiel, 1983, Nucci, 1981). Bir başka deyişle arkadaşımızla, yaşıtımızla, ya da hiç tanımadığımız bir başka vatandaşla gündelik ilişkimizde onun iyi oluş halini, haklarını, bize eşit olup olmadığını gözetip gözetmediğimizdir. Bu nedenle de ahlak kuralları evrenseldir ve diğer kültürel, geleneksel ve sosyal kurallardan farklılaşır. Sosyal Alan Kuramının diğer yapılandırmacı-aşamalı ahlak gelişim teorilerinden farkı yaklaşık 40 yılı kapsayan ampirik verilerle çocukların, ergenlerin ve yetişkinlerin ahlaki alanı sosyal geleneksel alandan kuralın genellenebilirliliği ve kuralın otoriteye bağlılığı kriterleri üzerinden nasıl farklılaştırdıklarını göstermesidir. Ahlaki ve Sosyal Kural AlgıSı Ölçeği (Seçer ve Sarı, 2006) kullanılarak yapılan okul öncesi çocuklarıyla yapılan araştırmalar ülkemizdeki çocukların ahlaki olanı sosyal-geleneksel olandan ayrıştırıp ayrıştıramadığını göstermemektedir. Bu kavramsal ayrıştırmayı göz ardı etmektedir. Buna ek olarak ülkemizdeki çalışmalar çocukların sosyal ve ahlaki gelişim düzeyinin ailelerinin sosyoekonomik düzeyine göre farklılaştığın işaret etmektedir (Akçinar, Baydar, \& Kağıtçıbaşı, 2018; Erel, 2016). Ancak bu çalışmamalarda ahlaki gelişim Piaget'nin dışa bağımlı aşaması üzerinden otoritenin koyduğu toplumsal kurallara uyum çerçevesinden tanımlanmaktadır.

Bu araştırmanın temel amacı, yukarıda kısaca tartışılmaya çalıştığımız kuramsal pozisyonlardan ve konuyla ilgili Türkçe alan yazından yola çıkarak Türkiye'nin üç farklı sosyo-ekonomik düzeyinden gelen okul öncesi dönemdeki çocukların sosyal hayat içerisinde kural ve otoriteye yönelik değerlendirmelerini araştırmaktır. Bu amaçla, 5 yaş grubu çocuklara basketbol ve evcilik oyununun kuralları ve otorite figürü olan öğretmenin kuralları değiştirmesine yönelik kısa hikayeler okunmuş, çocuklardan hikâyede geçen kuralları ve kurallara yönelik otorite müdahalesini değerlendirmeleri istenmiştir. Araştırmanın ilk sorusu çocukların basketbol ve evcilik oyunlarının kuralları hakkındaki bilgilerine yöneliktir. Çocuklara bu oyunların kuralları olup olmadığı ve eğer kural varsa bu kuralı kimin koyduğu sorusu sorulmuştur. Daha sonra basketbol bağlamında bilerek rakibe vurmak (faul yapmak) evcilik bağlamında verilen role girmemek davranışlarını değerlendirmeleri istenmiştir. Buradaki amaç çocukların bilerek vurmak eylemini oyun içerisinde ahlaki alan içerisinde değerlendirilip değerlendirmediğini görmek ve basketbolun kurallarının evcilik oyunun kurallarından nasıl farklılaştırdıklarını anlamaktır. Son olarak da çocukların gözünden öğretmenin otoritesinin nasıl değerlendirdiği araştırımıştır. Bu amaçla öğretmenin oyunun kuralı değiştirmesini ve öğretmen kuralı kaldırdıktan sonra durumu değerlendirmeleri istenmiştir.

\section{YÖNTEM}

\section{Araştırma Modeli}

Bu araştırmada veriler çocuklarla yapılan görüşmelerde toplanmıştır. Sosyal Alan Teorisince de benimsenen çocuklarda ve yetişkinlerde sosyal ve ahlaki sorgulamanın gelişimini yapılandırmacı teorik çerçeveyle analiz eden araştırmacıların başvurduğu bu yöntemin adı yüz yüze klinik görüşmedir (Mayer, 2005). Nicel bir araştırma yöntemi olan ve katılımcılara varsayımsal hikâyeler sunulmakta ve onlardan varsayımsal durumları değerlendirmeleri, değerlendirmelerini gerekçelendirmeleri istenmektedir. Yapılan görüşmeler analize tabi tutulmaktadır.

\section{Çalışma Grubu}

Bu çalışmaya 5 yaş grubundan anadili Türkçe olan toplam 37 çocuk katılmıştır. Katılan çocukların 21'i kız (\%57) 16'sı oğlandır. Yaş ortalaması kızlar için 64.58 (ss =3.91) oğlanlar için 65.58 (ss =2.97) aydır. Çalışmaya katılan çocuklar farklı sosyo-ekonomik düzeylere hitap eden okullardan seçilmiştir. Çocukların \%38'i İstanbul'da yüksek-gelir düzeyinden gelen ailelerin çocuklarının gittiği özel bir okul öncesi kurumundandır. Katılan çocukların \%30’u ise Çanakkale ili merkezinde orta sınıf ailelerin gittiği bir özel okul öncesi kurumunda eğitim görmektedirler. Katılımcı çocukların \%33’ü de sosyo-ekonomik ve sosyo-kültürel özellikler bakımından İstanbul ili ortalamasının oldukça altında yer alan bir mahalledeki devlet okulunun okul öncesi bölümüne devam etmektedirler. Okulun bulunduğu çevre Doğu ve Güney Doğu illerinden göç almış olan ve son zamanlarda da Suriyeli göçmen ailelerin yerleşmiş

| Kastamonu Eğitim Dergisi, 2020, Vol. 28, No. 31 
olduğu, gecekondu yapılarının çoğunlukta olduğu bir bölgedir.

\section{Veri Toplama Araçları}

Tüm katılımcı çocuklara bireysel olarak kurallarla oynanan oyunlarla ilgili kolayca anlayabilecekleri yaşlarına uygun iki ayrı hikâye okunmuştur. İki hikayedeki kuralların içeriği farklıdır. İlk hikâye fiziksel mücadeleye dayanan basketbol oyunu ile ilgilidir. Hikâye anlatılmadan önce katılımcı çocuklara ilk olarak "Basketbol oyununun herhangi bir kuralı olduğunu düşünüyor musun?" sorusu yöneltilmiştir. Katılımcı çocuğun verdiği cevap 'evet' ise, bu durumda "Bu kuralları kim koyuyor ve bu kurallar değiştirilebilir mi?" sorusu katılımcı çocuğa sorulmuştur. Daha sonra basketbol oyunu ile ilgili olan hikâyede bir çocuk basketbolun temel kurallarından biri olan faule aykırı davranarak, bilerek, isteyerek başka bir çocuğa zarar verecek, onu itip düşürecektir. Okunan hikayedeki bu itme düşürme davranışına istinaden katılımcı çocuğa yeni bir soru yönlendirilmiştir: 'Bu çocuğun diğerini bilerek, isteyerek itip düşürmesi davranışının uygun olduğunu düşünüyor musun ve neden?' Bu sorulardan sonra, hikayedeki olaya bir öğretmen dahil olmuş ve basketbol oyunundaki tüm kuralları kaldırdığını söylemiştir. Yani itmek, düşürmek gibi davranışlar artık yasak değildir. Okunan hikayedeki öğretmenin tüm kuralları kaldırması gelişmesine göre katılımcı çocuklara yeni sorular yöneltilmiştir. 'Öğretmen tüm kuralları kaldırdığında, basketbol oynarken bir çocuğun rakip çocuğu bilerek ve isteyerek itip düşürmesi sence doğru mudur ve neden?’

İkinci olarak okunan hikâyenin konusu ise evcilik oyunudur. Hikâye okunmadan önce katılımcı çocuklara "Evcilik oyununun herhangi bir kuralı olduğunu düşünüyor musun? Eğer varsa bu kurallara kim karar verir ve neden?” Bu hikâyede bir kız çocuğu evcilik oyunu oynarken, öğretmen rolüne girmesi kural olarak belirlenmiştir. Ancak çocuk öğretmen rolünde olmak ve okula gitmek istemediğini söyleyerek oyunun başında birlikte karar verdikleri kuralı çiğniyor. Hikâye okunduktan sonra katılımcı çocuklara basketbol hikayesindeki soruların aynısı sorulmuştur: "Evcilik oyununda çocuğun kuralları çiğnemesinin uygun olduğunu düşünüyor musun ve neden? Bu aşamadan sonra basketbol hikâyesinde olduğu gibi öğretmen gelip evcilik oyunundaki tüm kuralları kaldırdığını söylemiştir. Hikâyede öğretmenin gelip evcilik oyunundaki tüm kuralları kaldırdığını söylemesine istinaden katılımcı çocuğa tekrar şu soru sorulmuştur: "Sence öğretmenin evcilik oyununun kurallarını kaldırması doğru mudur ve neden? Ve öğretmen kuralı kaldırdıktan sonra kuralları çiğnemenin uygun olduğunu düşünüyor musun ve neden?"

\section{Veri Toplama Süreci}

Görüşmelere başlanmadan önce bir üniversitenin İnsan Araştırmaları Etik Komitesi'nden izin alınmıştır. Komiteden geçen veli onam formu esas alınarak görüşmeler sırasında sadece ses kaydı alınmış, alınan ses kaydı kimse ile paylaşılmadan deşifre edilmiş ve sonrasında silinmiştir. Deşifrelerde ve analizlerde çocukların kimliğini açık edecek hiçbir bilgi verilmemiştir. Her bir görüşme için yaklaşık olarak 15-20 dakika ayrılmıştır. Öğrencilerin katılımı için velilerinden Bilgilendirilmiş Ebeveyn Onay Formunu okuyup imzalamaları istenmiş ve kabul eden ebeveynlerin çocukları ile görüşmeler yapılmıştır. Çocuklar devam etmek istemedikleri ya da cevapsız kalmak istedikleri durumlarda kesinlikle ısrar edilmemiştir. Katılımcı çocukların sorulara cevap vermeleri sabır ile beklenmiş, onları rahatsız edecek, yönlendirici, acele ettirici her türlü tavırdan özenle kaçınılmıştır.

\section{Veri Kodlanması ve Güvenirlilik}

Çocukların oyunun kuralarını kim koyar sorusuna verdikleri cevap üç kategoride kodlanmıştır: (1) Otorite (2) Oyunu oynayanlar. Çocukların hikâyelerdeki durumlara yönelik değerlendirmeleri (1) evet, uygun, (2) hayır, uygun değil, şeklinde kodlanmıştır. Deşifre edilen görüşmelerde çocukların sunduğu gerekçeler Tablo 1'de gösterilen kodlama kriterlerine göre bağımsız iki kodlayıcı tarafından kodlanmıştır. Değerlendirme kategorileri arasında bağımsız kodlayıcılar arasında uyumsuzluk gözlenmemiştir. Kodlama kategorileri Sosyal Alan Kuramı kullanılarak yapılan diğer araştırmaların kodlama şeması dikkate alınarak geliştirilmiştir. Klinik görüşmelerle yapılan araştırmalarda güvenirlilik, bağımsız kodlayıcılar arasındaki uyum Cohen Kappa istatiksel metodu hesaplanarak belirlenir (McHugh, 2012). Bu araştırmada kodlayıcılar arasındaki uyum değerlendirmeler için .90, gerekçeler için .80 olarak bulunmuştur Kappa istatistiğine göre .60 ve üzeri olarak kabul edilebilir olarak belirlenmiştir (Landis \& Koch, 1977).

Tablo 1. Kodlama şeması

\begin{tabular}{lll}
\hline Alanı & Kriter & \multicolumn{1}{c}{ Örnek } \\
\hline Ahlaki & $\begin{array}{l}\text { Adalet } \\
\text { Haklar } \\
\text { İyi oluş hali }\end{array}$ & O zaman adil bir oyun olmaz. \\
& İtmek düşürmek kötü bir davranıştır. Çocuk diğer \\
arkadaşını düşürürse canı yanar. & \\
Sosyal-geleneksel & Öğretmenlerin rolleri, görevleri & Çocuk arkadaşını itip düşürürse öğretmen hakem \\
& & Öğretmenlik kıza yakışan bir meslektir. \\
& & Öğretmen ne derse o olur. \\
Kişisel & Kişisel tercih, özerklik & Eğer evcilikte çocuk öğretmen olmak istemiyorsa \\
& & olmayabilir, istediğini olabilir çünkü öğretmen \\
& & serbest zaman vermiştir. \\
& & Öğretmen olmasında bir sakınca yok çünkü \\
& & gerçekten olmuyor, oyunda olmuş oluyor.
\end{tabular}




\section{Veri Analizi}

Çocukların oyunun kurallarına yönelik genel soruya verdikleri cevaplar betimleyici istatiksel yöntemler kullanılarak analiz edilmiştir. Varsayımsal hikâyelerdeki kural ihlalini ve otoritenin müdahalesine yönelik değerlendirmelerinin analizinde ise çok faktörlü ANOVA kullanılmıştır. Gerekçelerin kategorik doğasından ötürü Kay-kare bağımsızlık testi kullanılarak analiz edilmiştir.

\section{BULGULAR}

Tablo 2 araştırmaya katılan çocukların basketbol ve evcilik oyunlarını kurallı oyunlar olarak değerlendirdiklerini ancak basketbol oyununun kurallarını evcilik oyununa kıyasla daha değiştirilemez bulduklarını göstermektedir. Ayrıca çocuklar, basketbol oyununda kural koyucu olarak otorite figürlerinden bahsederken, evcilik oyununda kural koyma yetkisini oyunu oynayan çocuklara vermişlerdir.

Tablo 2. Çocukların oyun bağlamında kural, kural değiştirme ve kural koyucuya yönelik değerlendirmeleri

\begin{tabular}{lcc}
\hline & Basketbol & Evcilik \\
\hline Kural var mı? & $\% 97$ & \\
Evet & & $\% 84$ \\
Kural değişir mi? & $\% 19$ & \\
Evet & $\% 73$ & $\% 37$ \\
Hayır & & \\
Kuralları kim koyar? & $\% 81$ & $\% 37$ \\
Otorite & $\% 8$ & $\% 51$ \\
Oynayanlar & & \\
\hline
\end{tabular}

Çocuklar, kural ihlâlini basketbol ve evcilik bağlamlarında farklı değerlendirmişlerdir, $F(1,31)=8.45, p<.01, \quad \eta^{2}=.21$. Basketbolda kural ihlali kesinlikle uygun bulunmazken, evcilik oyununda daha kabul edilebilir olarak değerlendirilmiştir (Bknz. Tablo 3). Çocukların değerlendirmelerinde cinsiyet ve SED farkı bulunmamıştır.

Tablo 3. Çocukların oyundaki kural ihlaline yönelik yargıları (1= Uygun değil)

\begin{tabular}{lc}
\hline & Ortalama (std sapma) \\
\hline Basketbolda faul yapmak & $1.00(.00)$ \\
Evcilikte role girmeme & $1.97(.07)$ \\
\hline
\end{tabular}

Tablo 4 farklı sosyoekonomik düzeydeki okulöncesi kurumlarına giden çocukların kural ihlaline yönelik değerlendirmeleri arasında istatiksel olarak anlamlı bir fark olmadığını göstermektedir. Basketbolda faul yapma kuralını ihlal eden oyuncu bütün çocuklar tarafından olumsuz değerlendirilmişlerdir. Evcilik oyununda ise kural ihlalini düşük sosyo-ekonomik düzeyden gelen çocuklar diğer çocuklara nazaran daha olumsuz değerlendirmişlerdir. Ancak bu fark istatiksel olarak anlamlı değildir, $\mathrm{F}(2,36)=$ $.38, p=.69$.

Tablo 5'te gösterildiği gibi yapılan Kay-Kare bağımsızlık testi çocukların basketbolda kural ihlal ederek rakibe vurma eylemini ahlaki olarak değerlendirirken evcilik oyunundaki kural ihlalini toplumsal-geleneksel alana ait bir mesele olarak gerekçelendirdiği göstermiştir, $p<.01$.

Tablo 4. Çocukların kural ihlaline yönelik yargılarının sosyoekonomik düzey açısından (SED) karşılaştırılması

\begin{tabular}{lcc}
\hline & Basketbolda faul & Evcilikte rolü red \\
\hline Düşük SED & $1.00(.00)$ & $1.00(.00)$ \\
Orta SED & $1.00(.00)$ & $1.36(.50)$ \\
Yüksek SED & $1.00(.00)$ & $1.21(.43)$ \\
\hline
\end{tabular}

Tablo 5. Çocukların kural ihlaline yönelik gerekçeleri

\begin{tabular}{lcc}
\hline & Basketbolda faul & Evcilikte rolü red \\
\hline Ahlaki & $\% 70$ & $\% 8$ \\
Toplumsal-geleneksel & $\% 7$ & $\% 56$ \\
Kişisel & ---- & $\% 19$ \\
\hline
\end{tabular}

Tablo 6'da gösterildiği gibi çocuklar iki farklı oyunda da otorite konumunda olan öğretmenin kuralları değiştirmesine yönelik değerlendirmeleri göstermektedir. Basketbolda öğretmenin faul kuralını kaldırması evcilikte rolleri kaldırmasından daha olumsuz bulunmuştur. Fakat bu fark istatiksel olarak anlamlı değildir.

| Kastamonu Eğitim Dergisi, 2020, Vol. 28, No. 31 
Tablo 6. Çocukların öğretmenin kuralı değiştirmesine yönelik yargıları (1= Uygun değil)

\begin{tabular}{lc}
\hline & Ortalama (std sapma) \\
\hline Basketbolda faul yapmak & $1.28(.09)$ \\
Evcilikte role girmeme & $1.44(.09)$ \\
\hline
\end{tabular}

Çocukların otoritenin kuralı değiştirmesine yönelik yargıları da sosyoekonomik düzey bakımından farklılaşmamaktadır. Basketbol oyununa müdahale eden öğretmen Tablo 7'de de gösterildiği gibi olumsuz olarak değerlendirilmiştir, $F(2,36)=1.23, p$ $=.30$. Evcilik oyununda ise düşük sosyoekonomik düzeyden gelen çocuklar otoritenin müdahalesini biraz daha olumlu değerlendirmişlerdir. Bu fark istatiksel olarak marjinal anlamlıdır, $F(2,36)=2.68, p=.08$.

Tablo 7. Çocukların kural öğretmenin kuralı değiştirmesine yönelik yargılarının sosyoekonomik düzey açısından (SED) karşılaştırılması (1= Uygun değil)

\begin{tabular}{lcc}
\hline & Basketbolda faul & Evcilikte rolü red \\
\hline Düşük SED & $1.33(.65)$ & $1.67(1.03)$ \\
Orta SED & $1.19(.40)$ & $1.72(1.01)$ \\
Yüksek SED & $1.36(.50)$ & $1.57(.65)$ \\
\hline
\end{tabular}

Kay-kare testi analizi ise (Bknz. Tablo 8) çocukların öğretmenin faul kuralını kaldırmasını ahlaki alanda gerekçelendirirken evcilik oyunundaki kuralı kaldırmasının toplumsal-geleneksel alana ait bir mesele olarak gördükleri göstermektedir, $p<.001$.

Tablo 8. Çocukların öğretmenin kuralları değiştirmesine yönelik gerekçeleri

\begin{tabular}{lcc}
\hline & Basketbolda faulü kaldırmak & Evcilikte rolleri kaldırmak \\
\hline Ahlaki & $\% 60$ & $\% 22$ \\
Toplumsal-geleneksel & $\% 22$ & $\% 51$ \\
Kişisel & $\% 3$ & $\% 8$ \\
\hline
\end{tabular}

Tablo 9 çocukların kural yokken davranışı yapmanın basketbol ve evcilik oyunlarında nasıl farklı değerlendirdiklerini göstermektedir, $F(1,31)=19.16, p<.01, \eta^{2}=.38$. Basketbol oynarken kural olmasa bile faul yapmak evcilik oyununda kural kalktığında role girmemekten daha olumsuz değerlendirilmiştir.

Tablo 9. Çocukların kuralın yokluğunda davranışı değerlendirmeleri

\begin{tabular}{lc}
\hline & Ortalama (std sapma) \\
\hline Basketbolda itmek & $1.03(.03)$ \\
Evcilikte role girmeme & $1.39(.09)$ \\
\hline
\end{tabular}

Tablo 10 ise çocukların kural yokken davranışı değerlendirmelerinin sosyoekonomik düzey açısından karşılaştırılmasını göstermektedir. Çocukların sosyoekonomik düzeyinin basketbolda kural yokken itme davranışına istatistiksel olarak anlamlı bir etkisi bulunmamıştır, $F(2,36)=1.20, p=.32$. Çocuklar itme davranılışını olumsuz değerlendirmişlerdir. Aynı şekilde evcilik oyununda kuralın olmadığı durumun basketbolda itmekten daha olumlu değerlendirildiği durumda da sosyoekonomik düzey farklılığı bulunmamaktadır, $\mathrm{F}(2,36)=.19, p=.83$.

Tablo 10. Çocukların kuralın yokluğunda davranışı değerlendirmelerinin sosyoekonomik düzey açısından karşılaştırılması

\begin{tabular}{lcc} 
& Basketbolda itmek & Evcilikte rolü reddetmek \\
\hline Düşük SED & $1.00(.00)$ & $1.33(.49)$ \\
Orta SED & $1.09(.30)$ & $1.45(.52)$ \\
Yüksek SED & $1.00(.00)$ & $1.35(.49)$ \\
\hline
\end{tabular}

Tablo 11'de gösterildiği gibi kural yoksa bile rakibi itmeyi ahlaki açıdan olumsuz değerlendirmişlerdir. Evcilik oyununda ise eğer öğretmen kuralı kaldırdıysa çocuğun davranışı kişisel seçim ya da toplumsal-geleneksel olarak gerekçelenmiştir, $p<.001$.

Tablo 11. Çocukların kural yokluğunda davranışı değerlendirmelerine yönelik gerekçeleri

\begin{tabular}{lcc} 
& Kural yoksa vurmak & Kural yoksa role girmemek \\
\hline Ahlaki & $\% 60$ & $\% 3$ \\
Toplumsal-geleneksel & $\% 19$ & $\% 27$ \\
Kişisel & $\% 5$ & $\% 51$ \\
\hline
\end{tabular}




\section{TARTIŞMA}

Bu araştırmada Piaget (1932/1968) ve Turiel'in (1983) gelişimsel yapılandırmacı kuramlarından yola çıkarak Türkiye'deki üç farklı sosyoekonomik düzeye hitap eden okulöncesi kurumlarına giden çocukların oyun bağlamında kural, kural ihlali ve otorite figürlerinin meşruluğuna yönelik değerlendirmeleri incelenmiştir. Araştırmanın sonuçları bize Türkiye'nin üç farlı sosyo-ekonomik düzeyinden gelen okulöncesi çağındaki çocukların ahlaki alan ile sosyal-geleneksel alanı ayrıştırdıklarını göstermektedir. Daha önce yapılmış çalışmaların bulgularıyla tutarlı olarak (Song, Smetana, \& Kim, 1987; Yau \& Smetana, 2003) bu çalışmaya katılan ve Türkçe konuşan okulöncesi çocukları da ahlaki kural ihlalinin sosyal-geleneksel alana yönelik kural ihlalinden daha yanlış olduğunu düşünmektedirler. Bu sonuç bize ahlaki ve sosyal-geleneksel bilgilerin Piaget (1932/1968) ve Kohlberg (1963) aşamalı kuramlarını tersine farklı zihinsel alanlarda geliştiğini göstermektedir. Türkiye gibi literatürde kültürel olarak ağırlıklı olarak kolektivist olarak tanımlanan batı dışı bir kültürde (Göregenli, 1997) bile çocuklar otoriteyi ve kuralları sorgulamakta, otoritenin kararlarını her durumda meşru görmemektedir. Ayrıca, yapılan analizler çocukların sorgulamalarının sosyo-ekonomik düzeyler, cinsiyet kimlikleri ve ailelerin kültürel düzeyi gibi değişkenler üzerinden farklılaşmadığını göstermiştir.

Çocuklar fiziksel mücadeleye dayanan basketbol oyununun faul kuralını evrensel ahlaki prensipler doğrultusunda değerlendirmişler, basketbol oynarken rakibe bilerek isteyerek zarar vermeyi "canı yanar, yaralanır, ağlar" gibi nedenlerle gerekçelendirmişlerdir. Öte yandan evcilik oyununun kurallarının değişmesine daha olumlu yaklaşmışlardır. Tıpkı değişik ülkelerde Sosyal Alan Kuramı kullanılarak yapılan araştırma sonuçlarının gösterdiği gibi bu çalışmaya katılan ve çocukların da otoriteye kayıtsız şartsız itaat etmediğini, özellikle oyun gibi çocukların kendi özerkliklerini deneyimledikleri bir bağlamda otorite ve kuralları sorguladıklarını göstermiştir. Çocuklar, evcilik oynarken kendi özerk seçimlerini öncelerken, bu oyundaki kuralları pazarlığa tabi bulmaktadırlar. Fakat kendi özerkliklerine öncelik tanımaları otoriteyi tanımadıkları anlamına da gelmemektedir. Katılımcı çocuklar, otorite figürü olarak görülen öğretmeni okulda düzeni sağlama yetkisini verdikleri için okulda oynadıkları evcilik oyununa da müdahale edebilip kuralı değiştirebilir olarak değerlendirmişlerdir. Fakat aynı öğretmene basketbolun rakibe fiziksel zarar verme kuralını değiştirme yetkisini vermemişlerdir. Daha önceki çalışmalarda da belgelendiği gibi (Davidson, Turiel, \& Black, 1983; Nobes \& Pawson, 2003) bu sonuçlar bize çocukların ahlaki alanla sosyal-geleneksel alanı zihinlerinde nasıl kavramsallaştırdıklarının otorite ve kurallara yönelik yargılarını da etkilediğini göstermektedir. Çocuklar ahlaki alandaki kuralların kim olursa olsun otorite tarafından değiştirilemeyeceğini, ahlaki davranışı düzenleyen kural olmasa bile o davranışın yanlış olduğunu söylemektedir (Song, Smetana, \& Kim, 1987; Smetana 1981; Smetana \& Braeges, 1990).

Ahlaki ve sosyal bilgilerin gelişimine yapısalcı açıdan yaklaşan Sosyal Alan Kuramı (Turiel, 1983) çocuğun aktif bir özne olarak sosyal bilgiyi karşılıklı sosyal etkileşimler içerisinde geliştirdiğini söyler. Bu açıdan bakıldığında, çocuğun sosyal ve ahlaki gelişimini desteklemek için çocuğun pasifleştirildiği, yukarıdan aşağıya dayatılan ve otoritelerce çerçevelenmiş değerler eğitimi müfredatı yerine okulöncesi dönemde çocukların spontan olarak oyunlar kurabilecekleri serbest oyun zamanlarına daha çok vakit ayrılmalıdır. Çocuklar arasındaki sosyal ve fiziksel etkileşimin arttıran değişik oyun aktiviteleri çocukların sosyal ve ahlaki sorgulama ve problem çözme becerilerinin gelişmesi için sayısız fırsat yaratacaktır. Oyun esnasında yetişkine düşen rol ise kuralları dikte etmek değil, çocukların "Hadi Oynayalım" çoşkusunu söndürmeden onlara ahlaki ve sosyal kuralar arasındaki farkıllaşmayı deneyimleyecek ortamları sağlamak ve oyun esnasında çocuklara birbirlerinin kişisel alanların sınırları konusunda rehberlik etmek olmalıdır.

Bu araştırmanın bulguları bize farklı sosyo-ekonomik düzeydeki mahallelerde büyüyen çocukların ahlaki sorgulamaları arasında istatiksel olarak anlamlı bir fark olmadığını göstermektedir. Ancak gerekçelerde orta ve yüksek gelir düzeyinden gelen çocukların düşük sosyo-ekonomik düzeyden gelen çocuklarla karşılaştıııldığında daha uzun cümleler kurdukları ve kelime dağarcıklarının daha zengin olduğu gözlemlenmiştir. Ayrıca değerlendirmelerini gerekçelendirirken düşük sosyo-ekonomik düzeyden gelen çocukların daha sık "bilmiyorum" dediği ve utangaç tavırlar sergiledikleri gözlemlenmiştir. Tıpkı Pozitif Ergen Projesi'nin (Akçinar, Baydar, \& Kağıtçıbaşı, 2018) bulgularının gösterdiği gibi dezavantajlı gruplara yönelik müdahale programlarının erken çocuk dönemindeki ahlaki sorgulamanın gelişimini de olumlu yönde etkileyeceği düşünülmektedir. Müdahale programlarını içeriğinin çocukların aktif katııımını sağlaması, çocukların karar alma süreçlerini dahil edilmesi ve "Çocuklarla Felsefe" gibi çocukları ahlaki ikilemler üzerine düşünmeye teşvik edecek etkinlikler olması erken çocukluk dönemindeki sosyal, ahlaki ve bilişsel gelişime katkı sağlayacaktır.

\section{SONUÇ VE ÖNERILER}

Bu araştırmanın sonuçları bize çocukların ahlaki alan ve sosyal geleneksel alanla ilgili konuları birbirinden ayırdığını ve bu konuları değerlendirirken farklı kriterler kullandıklarını göstermektedir. Ancak, sosyal bilgi alanlarının içinde yaş ve tecrübeyle birlikte ne gibi yapısal değişimler olduğu, ahlaki alan, sosyal-geleneksel alanın ve kişisel alanın nasıl etkileşip koordine edildiğini araştıran başka çalışmalara ihtiyaç vardır. Bu çalışmaların daha fazla katıımcıyla boylamsal olarak yapılması sosyal ahlaki gelişimi daha iyi anlamamızı sağlayacaktır.

Sosyal ve ahlaki gelişime zihindeki düşünme sisteminin yapılanması açısından bakan yaklaşımlar için çocuğun kendi yaşıtlarıyla yaptığı arkadaşık ve oyunların önemine dikkat çekmiştir. Bu yaklaşımlar açısından okul öncesi eğitimde çocuklara akademik bir müfredatla "değerlerin aktarılması" yerine çocukların evrensel ahlaki normları ve evrensel olmayan sosyal-kültürel kuralları kendi kendilerine deneyimleyecekleri alanlar açmak çok önemlidir. Burada öğretmenin görevi doğru ve yanlışı dikte etmek değil, çocuğu neden doğru, neden yanlış konusunda sorgulamaya teşvik etmektir. Eşitler arası bir ilişki olan arkadaşlık ve arkadaşlarla birlikte

| Kastamonu Eğitim Dergisi, 2020, Vol. 28, No. 3 | 
kurulan, bozulan ve yeniden kurgulanan oyunlar çocuklara aynı zamanda kendi kişisel tercihlerini dile getirme, kendi sınırlarını ve özerkliğini oluşturma fırsatı da verecektir.

\section{KAYNAKÇA}

Akçinar, B., Baydar, N., \& Kağıtçıbaşı, Ç. (2018). Erken ergenlikte ahlak gelişimi: Bir müdahale araştırması. Eğitimde Kuram ve Uygulama, 14(2), 153-169. doi:10.17244/eku.322365.

Bandura, A. (2002). Selective moral disengagement in the exercise of moral agency. Journal of Moral Education, 31(2), $101-119$.

Davidson, R, Turiel, E., \& Black, A. (1983). The effect of stimulus familiarity on the use of criteria and justifications in children's social reasoning. British Journal of Developmental Psychology, 1, 49-65.

Durkheim, E. (1925/1961). Moral education. Mineola, NY: Dover Publications.

Erel, S. (2016). Okul öncesi dönemdeki çocuklarda bakış açısı alma becerisi, duygu düzenleme ve ahlaki gelişimin davranış sorunları ile ilişkisi. Basılmamış Master Tezi. Ankara, Hacettepe Üniversitesi.

Göregenli, M. (1997). Individualist-Collectivist Tendencies in a Turkish Sample. Journal of Cross-Cultural Psychology, 28(6), 787794. https://doi.org/10.1177/0022022197286009

Killen, M., \& Sueyoshi L. (1995) Conflict resolution in Japanese social interactions. Early Education and Development, 6, 317334, DOI: 10.1207/s15566935eed0604_3

Kohlberg, L. (1963). The development of children's orientation towards a moral order. Vita Humana, 6, 11-33.

Landis, J. R., \& Koch, G. G. (1977). An application of hierarchical Kappa-type statistics in the assessment of majority agreement among multiple observers, Biometrics, 3, 364-373.

Laupa, M., \& Turiel, E. (1986). Children's conceptions of adult and peer authority. Child Development, 405-412.

Laupa, M., \& Turiel, E. (1993). Children's concepts of authority and social contexts. Journal of Educational Psychology, 85(1), 191.

Nucci, L. P. (1981). The development of personal concepts: A domain distinct from moral or societal concepts. Child Development, 52(1), 114121.

Mayer, S. (2005). The early evolution of Jean Piaget's clinical method. History of Psychology, 8, 362-82. 10.1037/1093-4510.8.4.362.

McHugh, M. (2012). Interrater reliability: The Kappa statistics. Biochem Med, 22, 3, 276-282.

Meriç, A., \& Özyürek, A. (2018). Okulöncesi dönem çocukların ahlaki ve sosyal kural bilgilerinin incelenmesi. Uluslararası Toplum Araştırmaları Dergisi, 8(14), 137-166.

Oruç, N. (2010). Okul öncesi dönem çocuğunda değerler eğitimi. Eğitim ve Insani Bilimler Dergisi, 1,37-60.

Özyürek, A., \& Şahin, F.T. (2015). Anne-çocuk ilişkisinin ve baba tutumlarının çocukların ahlaki ve sosyal kural anlayışları üzerine etkisi. Eğitim ve Bilim, 40, 161-174.

Piaget, J. (1932/ 1968). The moral judgment of the child. Middlesex, England: Penguin Books.

Seçer, Z., \& Sarı, H. (2006). Okul öncesi eğitim kurumuna devam eden ve etmeyen çocukların ahlâki ve sosyal kural bilgilerinin çeşitli değişkenler açısından karşılaş̧ırmalı olarak analizi. Milli Eğitim Dergisi, 172, 126-142.

Seçer, Z., Sarı, H., \& Olcay, O. (2006). Anne tutumlarına göre okulöncesi dönemdeki çocukların ahlaki ve sosyal bilgilerinin incelenmesi. Selçuk Üniversitesi Sosyal Bilimler Enstitüsü Dergisi, (16), 539-557.

Seçer, Z., Çeliköz, N., \& Yaşa, S. (2008). Okul öncesi Dönemdeki Çocukların Bilişsel Stillerine Göre Ahlaki ve Sosyal Kural Anlayışları, Selçuk Üniversitesi Sosyal Bilimler Enstitüsü Dergisi, 20, 561-576.

Skinner, B. F. (1971). Beyond freedom and dignity. Cambridge, IN: Hackett Publishing

Smetana, J. G. (1981). Preschool children's conceptions of moral and social rules. Child Development, 52, 1333-1336.

Smetana, J. G., \& Braeges, J. L. (1990). The development of toddlers' moral and conventional judgments. Merrill-Palmer Quarterly, 36, 329-346.

Song, M., Smetana, J., \& Kim, S. Y. (1987). Korean children's conceptions of moral and conventional transgressions. Developmental Psychology, 23, 577-582.

Turiel, E. (1983). The development of social knowledge: Morality and convention. Cambridge: Cambridge University Press.

Yau, J., \& Smetana, J. G. (2003). Conceptions of moral, social-conventional, and personal events among Chinese preschoolers in Hong Kong. Child Development, 74: 647-658. doi:10.1111/1467-8624.00560 